\title{
Glacial Geomorphology of Mt. Asralt Khairkhan and Mt. Baga Khentii Saridag in Khentii Mountain Range, Northeastern Mongolia
}

\author{
Alexander Orkhonselenge, Munkhjargal Uuganzaya \\ Laboratory of Geochemistry \& Geomorphology, School of Arts \& Sciences, National University \\ of Mongolia, Ulaanbaatar, Mongolia \\ Email:rkhnslng@num.edu.mn
}

How to cite this paper: Orkhonselenge, A. and Uuganzaya, M. (2018) Glacial Geomorphology of Mt. Asralt Khairkhan and Mt. Baga Khentii Saridag in Khentii Mountain Range, Northeastern Mongolia. International Journal of Geosciences, 9, 308-319. https://doi.org/10.4236/ijg.2018.96019

Received: May 15, 2018

Accepted: June 11, 2018

Published: June 14, 2018

Copyright $\odot 2018$ by authors and Scientific Research Publishing Inc. This work is licensed under the Creative Commons Attribution International License (CC BY 4.0).

http://creativecommons.org/licenses/by/4.0/

\begin{abstract}
This study provides a map of glacial geomorphology of Mt. Asralt Khairkhan and Mt. Baga Khentii Saridag in Khentii Mountain Range in northeastern Mongolia. In the Khentii Mountain Range, only two types of glacial landforms including glacial cirques and terminal moraines are observed for the paleoglacial reconstructions of Mt. Asralt Khairkhan and Mt. Baga Khentii Saridag, and are mapped based on a mapping from $30 \mathrm{~m}$ resolution ASTER DEM and Landsat 8 satellite imagery. Spatial distribution of the glacial landforms indicates that the Khentii Mountain Range has experienced valley glaciations with small ice caps centered on the high mountains. The glacial cirques mark numerous glacial erosional landforms, while the terminal moraines indicate glacial advances and depositional landforms at outlets of valleys. Outer limits of these glacial landforms show their maximum glaciation of $10.0 \mathrm{~km}^{2}$ and 0.7 $\mathrm{km}^{2}$ for Mt. Asralt Khairkhan and Mt. Baga Khentii Saridag, respectively. This study demonstrates that spatial analysis of the glacial landforms is crucial for reviewing the paleoglacier extent. The map of the glacial geomorphology will be a key for further detailed studies in paleoglaciology and paleoclimate of the mountain range.
\end{abstract}

\section{Keywords}

Glacial Landforms, Paleoglaciers, Khentii Mountain Range, Mongolia

\section{Introduction}

Reconstructing paleoglaciers is in efforts critical to understanding climate change in the past, glacier behavior and sensitivity to climate change, i.e., reconstructing the paleo record of the paleoglacier changes contributes to under- 
standing how glaciers vary with climate change, and provides opportunities to reconstruct paleoclimates. Mountain glaciers respond sensitively to local-to-regional patterns of climate change which are driven by global-scale processes. Paleoglacier evolution in high mountains is the key parameter for a reliable prediction of future glacier change. Determinations of paleoglacier extent during glacial maximums and paleoclimatic reconstructions are still a challenge.

In Mongolia, evidence for paleoglaciers has been widely found in the Altai, Khangai, Khuvsgul and Khentii Mountain Ranges (Figure 1) because the four mountain ranges were glaciated in Pleistocene [1], three to four times in the Altai, twice to three times in the Khangai and Khuvsgul, and one in the Khentii [2]. The extent of paleoglaciation in Mongolia is the greatest in the north and west compared to the south and east, and this trend is also observed for modern glaciers [1] [2]. The dominant style of glaciations recorded in the landforms and deposits of Mongolia is valley glaciations [1] [2]. The Khentii Mountain Range differs as only one mountain range where the modern glaciers do not take still place today, compared with other three mountain ranges, namely the Altai, Khangai and Khuvsgul in Mongolia (Figure 1). There has been a lack of work reconstructing long-term glacier fluctuations. The purpose of this paper is to provide a reconstruction of paleoglaciers for Khentii Mountain Range in northeastern Mongolia.

There is still poor scientific information about the spatial and temporal paleoglaciers including their extents and chronology in Khentii Mountain Range, compared with other Altai, Khangai and Khuvsgul Mountain Ranges, even in the World Glacier Inventory or in the database of the US National Snow and Ice Data Center. In other words, no any detailed studies except for the studies by Tsegmid [3] and Jigj [2] have been completed in the Khentii, where the paleoglacier remains have been abundant [2]. To date, a numerous of glacial studies were done in Altai Mountain Range in western Mongolia where geomorphological map containing detailed individual glacial landforms in Mt. Tsambagarav was compiled by Blomdin et al. [4]. Recent glacier changes of Mt. Munkh Khairkhan and Mt. Tavan Bogd in Mongolian Altai Mountain Range were provided by Krumwiede et al. [5]. Pleistocene glacial moraine sequences of Mt. Otgon Tenger in Khangai Mountain Range in central Mongolia were detected by Rother et al. [6]. Data on morphometric changes in area and volume of the modern glaciers in Khuvsgul Mountain Range in northern Mongolia (e.g. [7] [8] [9]), and intensive retreats of the glaciers in Little Ice Age, especially in recent decades under rising temperature [10] [11] [12] [13] were observed based on aerial photographs, satellite images, topographic maps, remote sensing images and in-situ observation data. However, an absence of any such study is in Khentii Mountain Range. In this study, therefore, paleoglacier extent and glacial landforms in individual Mt. Asralt Khairkhan and Mt. Baga Khentii Saridagare presented on glacial geomorphological maps in order to underpin paleoglacial 


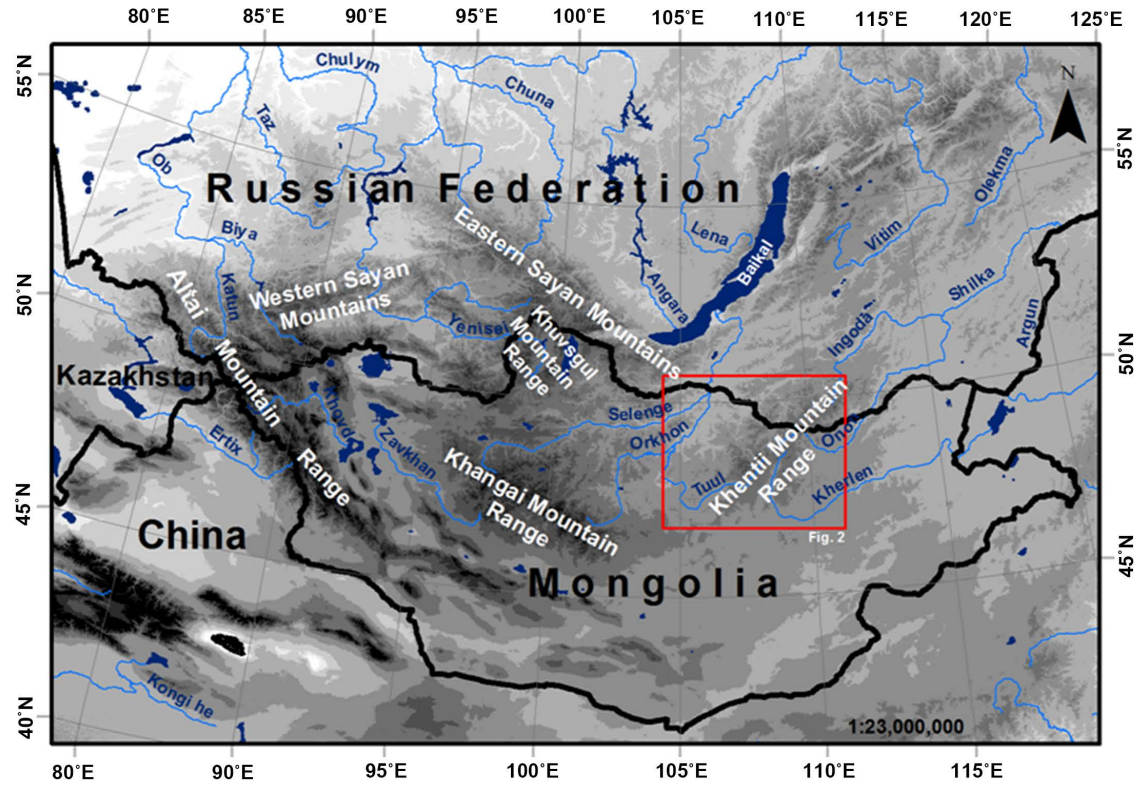

Figure 1. Location of mountain ranges in Mongolia. Red box denotes the location of Khentii Mountain Range, study area presented in detail in Figure 2.

reconstructions in the Khentii Mountain Range in northeastern Mongolia (Figure 1, Figure 2).

It is important to understand paleoglacier extent of the Mt. Asralt Khairkhan and Mt. Baga Khentii Saridag. The studies [1] [2] provided evidence for restricted Pleistocene glaciations in Khentii Mountain Range. The Khentii Mountain Range was experienced in glaciation once during Pleistocene period centered on Mt. Asralt Khairkhan, Mt. Khiid Saridag, Kherkhluur Saridag, and heads of Rivers Minj, Zakhar, Iluur, Terelj and Kherlen covering $50-100 \mathrm{~m}$ thick glaciers [2]. In Khentii Mountain Range lateral and terminal moraines, hummocky terrains, glacial cirques [2], U-shaped valley, hanging valley, fluvio-glacial terraces [1], and glacial lakes are abundant. Paleoglacial imprints have been preserved well in high mountains at above $1750 \mathrm{~m}$ a.s.l, and carved landforms as being as paleoglacial imprints are widely found at heads of Rivers Khiid, Khag, Shoroot, Minj and Iluur draining the Khentii Mountain Range [14]. Although a total paleoglacier area in the Khentii Mountain Range is unclear until today, Jigj [14] calculated it as an area of $1760 \mathrm{~km}^{2}$ based on aerial photo, topographical map and field data. A gap extending $12-15 \mathrm{~km}$ long between the cirques and terminal moraines provides an expectation of that paleoglacier may have been extented in such distance [14]. This study aims to present detailed data on paleoglacier remnants in Mt. Asralt Khairkhan and Mt. Baga Khentii Saridagin Khentii Mountain Range based on interpretations of Landsat images and analyses of ASTER DEM satellite images. Thus the existing works suggest the spatial variations recorded by glacial landforms across the Mt. Asralt Khairkhan and Mt. Baga Khentii Saridag, however far more work on temporal variations is required to elucidate these patterns based on dating because as little is known 


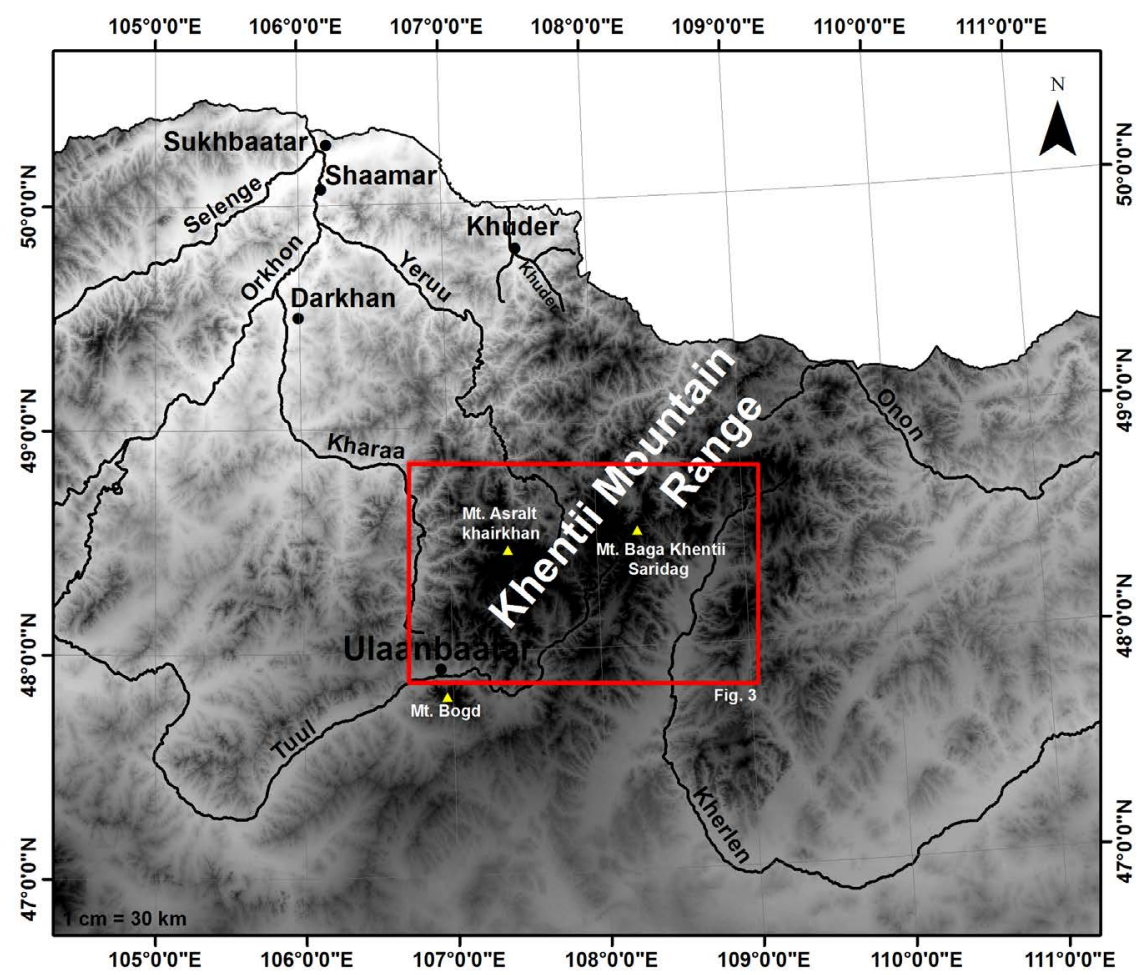

Figure 2. Topography of Khentii Mountain Range. Red box denotes the location of study area presented in Figure 3.

about the paleoenvironmental and paleoclimatic history of northeastern Mongolia.

\section{Site Description}

The Khentii Mountain Range extends southwest-northeast trends from its most southwestern tip, the Mt. Bogd, to the Russian border in the northeast of Mongolia (Figure 1, Figure 2), with a mean elevation of $1600 \mathrm{~m}$ a.s.l (extending from $2800 \mathrm{~m}$ a.s.l. of Mt. Asralt Khairkhan in the highest part to $600 \mathrm{~m}$ a.s.l. of the estuary of River Yeruu in the lowest part). In other words, the Khentii Mountain Range extends from the northeastern corner of Mongolia towards the southwest, where it becomes the most southern end of the Siberian wetland, merging into the prairie of central Mongolia (Figure 1). The Khentii Mountain Range is surrounded by the valleys of the River Onon in the east, River Kherlen in the southeast, of River Tuul in the southwest, of River Orkhon in the west and Rivers of Kharaa and Yeruu in the northwest (Figure 2). The Khentii Mountain Range is predominantly composed of early Paleozoic and Mesozoic granites, and consists of dome-shaped tops, peaks with steep gorges and cliffs, and valleys with gentle slopes formed by the Cenozoic glaciations [1] [15]. The climate of this range is characterized by large annual temperature variations [16]. The large Rivers Onon, Kherlen, Terelj, Tuul, Kharaa, Yeruu drain the Khentii Mountain Range (Figure 2) into Atlantic and Pacific Ocean Basins [16]. The 
Khentii Mountain Range is known for its high diversity of vegetation types going from Siberian taiga forests to Mongolian steppe vegetation [17].

Mt. Asralt Khairkhan, one of our study areas, is located in the center of the Khentii Mountain Range (Figure 2). Mt. Asralt Khairkhan is the peak of the Khentii Mountain Range and is situated at an elevation of $2800 \mathrm{~m}$ a.s.l. According to a meteorological station in Terelj village (Figure 3), locating $61 \mathrm{~km}$ south of the Mt. Asralt Khairkhan and at an elevation of $1530 \mathrm{~m}$ a.s.l, the annual mean precipitation is $225.3 \mathrm{~mm}$ (ranging from $1.4 \mathrm{~mm}$ in January to $76.2 \mathrm{~mm}$ in July), and the annual mean air temperature is $-3.3^{\circ} \mathrm{C}$ (ranging from $-21.6^{\circ} \mathrm{C}$ in January to $13.0^{\circ} \mathrm{C}$ in July) [18]. Rivers Khongor, Asralt and Khurkhree drain Mt. Asralt Khairkhan [19].

Mt. Baga Khentii Saridag, another one of our study areas, is located at an elevation of $2534 \mathrm{~m}$ a.s.l. on the center of the Khentii Mountain Range (Figure 2). According to a meteorological station in Mungun Morit soum (Figure 3), locating $56 \mathrm{~km}$ south of the Mt. Baga Khentii Saridag and at an elevation of $1437 \mathrm{~m}$ a.s.l, the annual mean precipitation is $255.6 \mathrm{~mm}$ (ranging from $1.5 \mathrm{~mm}$ in January to $83.4 \mathrm{~mm}$ in July), and annual average air temperature is $-2.65^{\circ} \mathrm{C}$ (ranging from $-24.2^{\circ} \mathrm{C}$ in January to $16.1^{\circ} \mathrm{C}$ in July), a tributary of River Shoroot drains Mt. Baga Khentii Saridag [19].

\section{Method}

In this study, Landsat 8 image at row of 26 and path of $131(08 / 24 / 2013)$, ASTER Global DEM (AGDEM), and Google Earth are used for determining glacial landforms and for reconstructing paleoglacier extent of Mt. Asralt Khairkhan and Mt. Baga Khentii Saridag in Khentii Mountain Range. Because of that determinations of glacial erosional and depositional landforms are keys to paleoglaciological studies [4], paleoglacier extent of Mt. Asralt Khairkhan and Mt. Baga

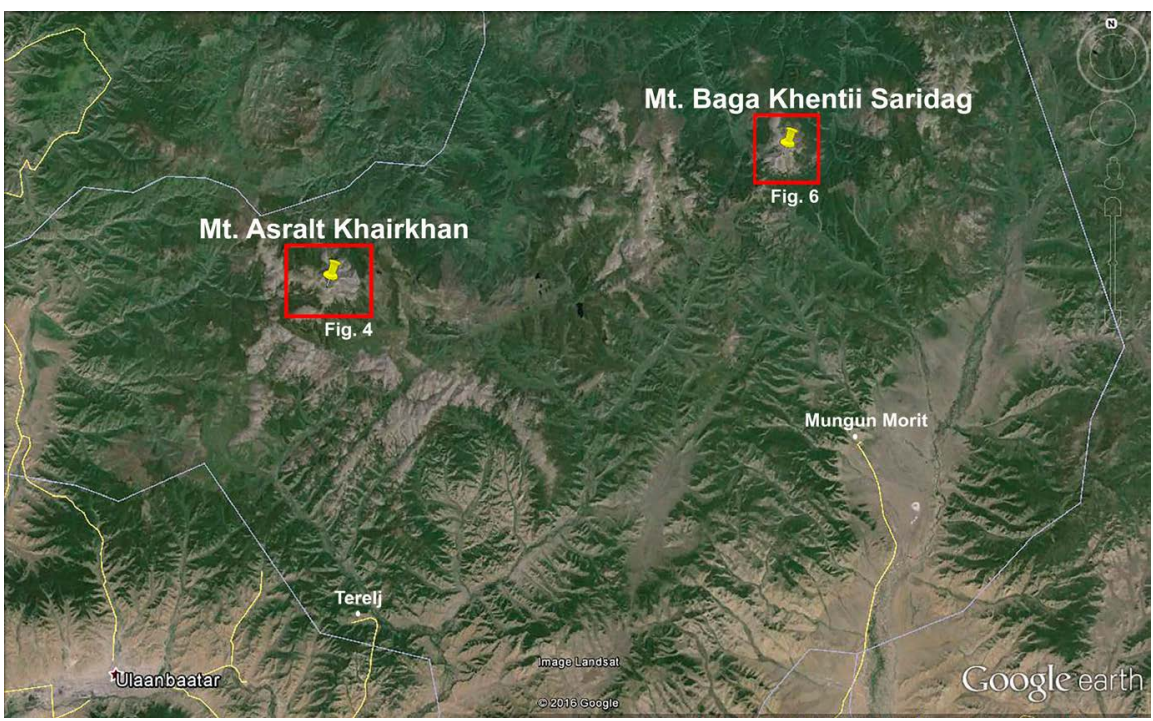

Figure 3. Topography of study areas (Mt. Asralt Khairkhan and Mt. Baga Khentii Saridag) and location of meteorological stations (Terelj and Mungun Morit). 
Khentii Saridag was reconstructed with visual interpretation of remotely sensed data following a set of criteria [4] [20] [21] [22] [23] [24].

A combination of Landsat 8 imagery $(30 \mathrm{~m}$ resolution) and AGDEM $(30 \mathrm{~m}$ resolution) was used as the primary data source for compiling on-screen digitizing of the glacial landforms. In order to delineate the glacial landforms, Google Earth's 3D viewing capability and RGB band combinations of true (RGB: 7, 4, 2) and false (RGB: 4, 3, 2) color composites of Landsat 8 imagery (Figure 4(a), Figure 4(b), Figure 6(a), Figure 6(b)) were used. From the AGDEM data, slope models to display slope steepness (Figure 4(c), Figure 6(c)) and hill shade models to simulate solar shading (Figure 4(d), Figure 6(d)) were computed. These models were set with $50 \%$ transparency and draped over the original AGDEM data to enhance the topographic signature of glaciated terrains. Conventional colors are used for other background information such as lakes and rivers (Figure 4(a), Figure 6(a)). Glacial cirques (GC) and terminal moraines (EM) are displayed in green and yellow, respectively (Figure 4(a), Figure 6(a)).

\section{Results and Discussion}

Glacial landforms in Khentii Mountain Range are compiled on glacial geomorphological map (Figure 4, Figure 6). The Khentii Mountain Range has experienced to glaciations once in the Quaternary period [1] [2]. Overall, for the Khentii Mountain Range (Figure 2), only the Mt. Asralt Khairkhan and Mt. Baga Khentii Saridag preserve a few of paleoglacier remains including cirquesand moraines (Figures 4-6) on north and south aspects (Figure 4(a), Figure 4(b), Figure 6(a), Figure 6(b)).

\subsection{Glacial Landforms}

On the maps, glacial landforms were identified as glacial cirques and terminal moraines. Descriptions for the glacial landforms in Khentii Mountain Range are mainly based on the landform descriptions in Tibetan Plateau, Altai and Sayan Mountain Ranges in Central Asia [4] [20] [21] [22] [23].

\subsubsection{Glacial Cirques}

Glacial cirques are formed in a bowl-shaped depression on the side near mountains [25]. Although Heyman et al. [20] and Blomdin et al. [4] included the cirques in the category of glacial valleys, they have been identified in individual category in this study. It has been predicted as their identifications as that if a glacial cirque advances far enough, it may become a valley glacier. On the contrary, it is a cirque glacier because a valley glacier retreats enough that it is within cirques [26]. Snow may be situated on the leeward slope of a mountain, where it is sheltered from wind and rock fall from above slopes also plays an important role in sheltering the snow and ice from sunlight [26]. In Mt. Asralt Khairkhan and Mt. Baga Khentii Saridag, glacial cirques clearly observed are identified in Landsat imagery and AGDEM (Figure 4(a), Figure 4(b) [GC]; Figure 5; Figure 6(a), Figure 6(b) $[G C])$. 

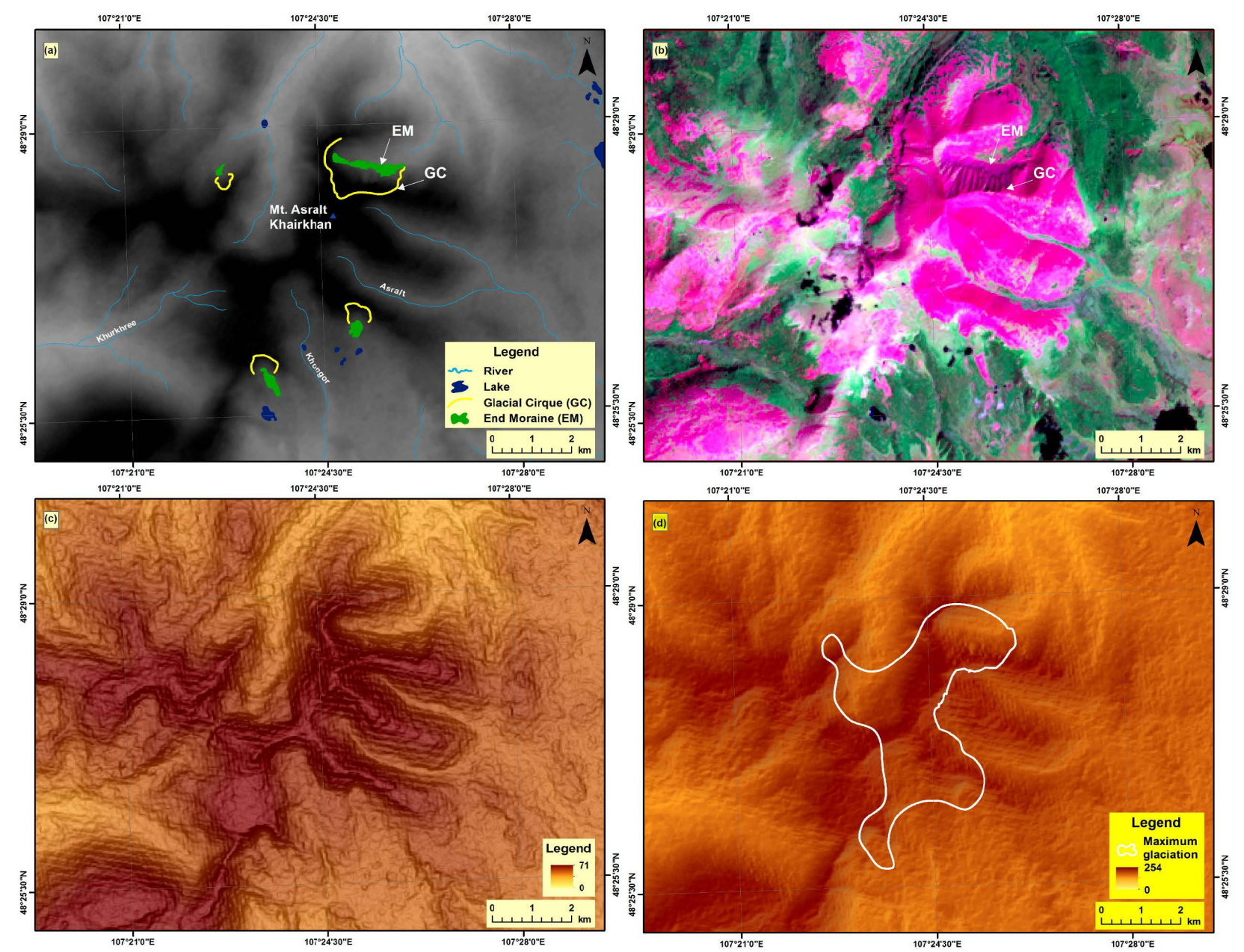

Figure 4. Mt. Asralt Khairkhan: (a) Glacial landforms and a grey-scale AGDEM, (b) False Landsat 8 imagery, (c) Colored AGDEM draped by a semi-transparent grey-scaleslope model, and (d) Colored AGDEM draped by a semi-transparent grey-scalehill shade model with the maximum paleoglacier reconstruction.

\subsubsection{Terminal Moraines}

Terminal or end moraines are ridges of unconsolidated debris deposited at the snout or end of the glacier, i.e., if the material pushed in front of the glacier is left, this material is called a terminal/end moraine. They usually reflect the shape of the glacier's terminus and the more debris accumulates in the end moraine [25].

Glaciers act much like a conveyor belt as carrying debris from the top of the glacier to the bottom where end moraines form. Size and shape of end moraine are determined by whether the glacier is advancing, receding or at equilibrium. Sizes of end moraine vary from smaller ridges with areas less than a couple of meters wide and tens of meters long to larger complexes more than $100 \mathrm{~km}^{2}$ areas [4]. The end moraines mark the maximum advance of the glacier. In Mt. Asralt Khairkhan, clearly exposed end moraines are most easily identified in Landsat imagery and AGDEM (Figure 4(a), Figure 4(b) [EM]). There is the largest end moraine at $2018 \mathrm{~m}$ a.s.l, which mark paleoglaciers advanced far away (Figure 4(a), Figure 4(b) [EM]). 


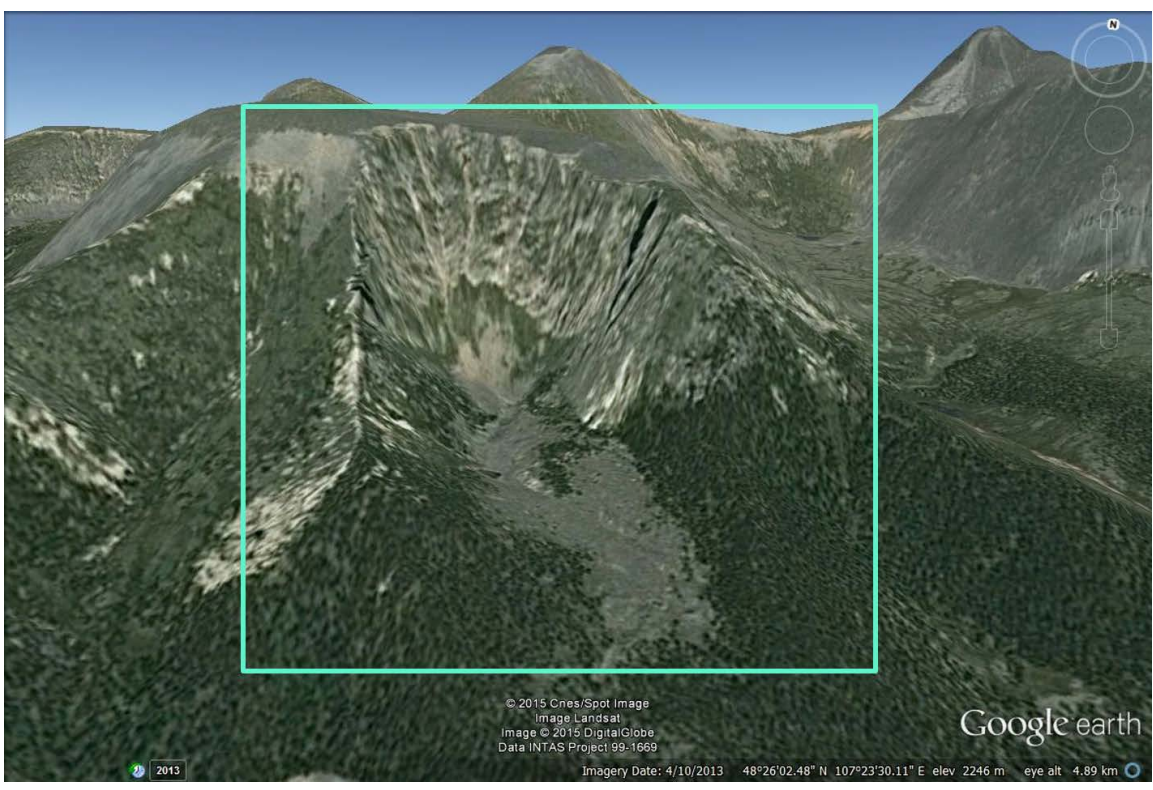

Figure 5. Glacial cirque of the Mt. Asralt Khairkhan.

\subsection{Paleoglacier Extent}

For spatial reconstruction on paleoglacier extent in the Mt. Asralt Khairkhan and Mt. Baga Khentii Saridag in Khentii Mountain Range, the aerial extent of paleoglaciation based on the distribution of glacial landforms described above (see Section 4.1) is estimated. The maximum glacier extents were delineated in the GIS environment using the margins of the glacial cirques and terminal moraines (Figure 4(d), Figure 6(d)). This method enables a straightforward delineation of the maximum glacier extent in formerly glaciated mountain regions using the glacial landforms [4]. This reconstruction based on remote sensing represents the minimum extent of maximum glaciation, i.e., this paleoglaciological footprint yields a useful estimate of paleoglacier coverage based on the distribution of glacial landforms and allows for a comparison with the modern glacier extent (e.g. [4] [27]). Consistency and accuracy of the glacial geomorphological mapping have been strictly strengthened by previous mapping procedures [4] [20] [21] [22] [23] [24]. In this study, the reconstructed paleoglacier extents in Mt. Asralt Khairkhan (Figure 4(d)) and Mt. Baga Khentii Saridag (Figure 6(d)) are calculated from the Randolph Glacier Inventory V3.2. The maximum glaciation areas are reconstructed by $10.0 \mathrm{~km}^{2}$ and $0.7 \mathrm{~km}^{2}$ for Mt. Asralt Khairkhan and Mt. Baga Khentii Saridag, respectively (Figure 4(d), Figure 6(d)).

Results in this study reconstruct spatial extents on the maximum paleoglaciations of the Mt. Asralt Khairkhan and Mt. Baga Khentii Saridag in Khentii Mountain Range. Furthermore, the spatial analyses contribute to have been predicted that paleoglaciers near $48^{\circ} \mathrm{N}-49^{\circ} \mathrm{N}$ in northeastern Mongolia may have retreated with faster rate for these individual mountains depending on geographical position in southern latitudes and vulnerability of the glaciers to solar 

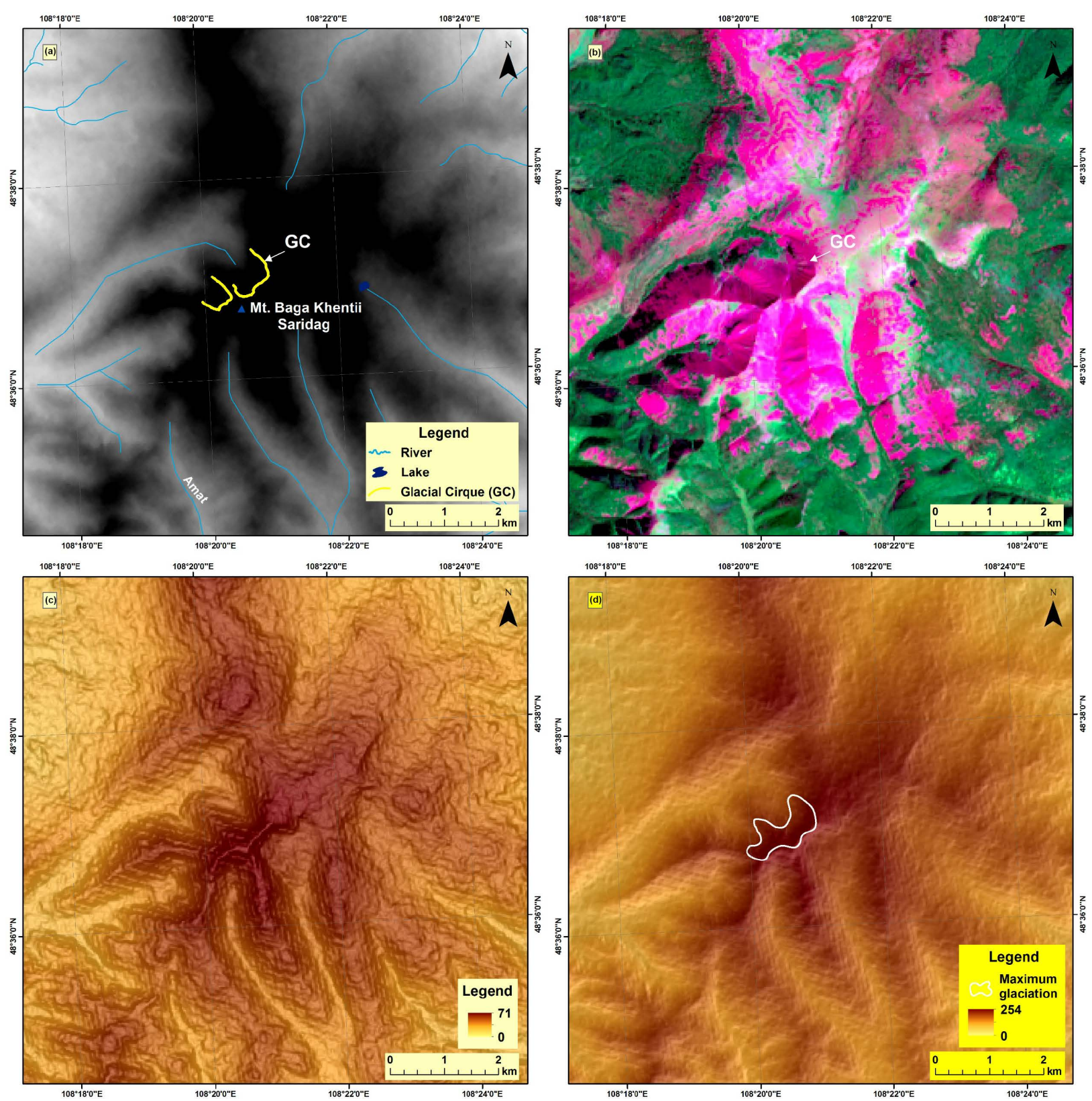

Figure 6. Mt. Baga Khentii Saridag: (a) Glacial landforms and a grey-scale AGDEM, (b) False Landsat 8 imagery, (c) Colored AGDEM draped by a semi-transparent grey-scaleslope model, and (d) Colored AGDEM draped by a semi-transparent grey-scalehill shade model with the maximum paleoglacier reconstruction.

insolation. This prediction could be clearly reflected on temporal information from the age of past ice advances in Khentii Mountain Range in further study.

\section{Conclusion}

Paleoglacier extents of Mt. Asralt Khairkhan and Mt. Baga Khentii Saridag in Khentii Mountain Range in northeastern Mongolia have been spatially reconstructed as $10.0 \mathrm{~km}^{2}$ and $0.7 \mathrm{~km}^{2}$, respectively. With the reconstruction with glacial landforms, large terminal moraines formed by glacial advances are mainly 
located at outlets of the glacial cirques. By determining the maximum paleoglaciers, as indicated by the distributions of preserved glacial landforms, the spatial analyses of the glacial cirques and terminal moraines indicate that this mountain range was covered by valley glaciations in the past as the Altai, Khangai and Khuvsgul Mountain Ranges in Mongolia. This study shows that in the Khentii Mountain Range, the spatial distribution of paleoglaciersare reconstructed relatively less than those in other mountain ranges. The spatial analyses for reconstructing paleoglaciers would be detailed with extensive fieldwork and dates in further work in order to verify temporal distribution of the paleoglaciers.

\section{Acknowledgements}

We would like to thank National University of Mongolia for the research grant (N3S2015SAS-7) for Early Career Researchers, and Dr. Robin Blomdin of Stockholm University for advice on remote sensing and mapping. We are also grateful to reviewers for helpful suggestions and constructive comments.

\section{References}

[1] Tsegmid, Sh. (1969) Physical Geography of Mongolia. Ulaanbaatar, 759 pp. [In Mongolian]

[2] Jigj, S. (1976) A Brief Description of Paleoglaciations and Paleoglaciers. Ulaanbaatar, 51 pp. [In Mongolian]

[3] Tsegmid, Sh. (1953) Paleoglaciers in the Khentii Mountain Range. Geographical Issue of Mongolia, 2, 43-57.

[4] Blomdin, R., Heyman, J., Stroeven, A.P., Hattestrand, C., Harbor, J.M., Gribenski, N., Jansson, K.N., Petrakov, D.A., Ivanov, M.N., Orkhonselenge, A., Rudoy, A.N. and Walther, M. (2016) Glacial Geomorphology of the Altai and Western Sayan Mountains, Central Asia. Journal of Maps, 12, 123-136. https://doi.org/10.1080/17445647.2014.992177

[5] Krumwiede, B.S., Kamp, U., Leonard, G.J., Kargel, J.S., Dashtseren, A. and Walther, M. (2014) Chapter 22 Recent Glacier Changes in the Mongolian Altai Mountains: Case Studies from Munkh Khairkhan and Tavan Bogd. In: Kargel, J.S., et al., Eds., Global Land Ice Measurements from Space, Springer-Verlag Berlin Heidelberg, 481-508. https://doi.org/10.1007/978-3-540-79818-7_22

[6] Rother, H., Lehmkuhl, F., Fink, D. and Nottebaum, V. (2014) Surface Exposure Dating Reveals MIS-3 Glacial Maximum in the Khangai Mountains of Mongolia. Quaternary Research, 82, 297-308. https://doi.org/10.1016/j.yqres.2014.04.006

[7] Krivonogov, S.K., Sheinkman, V.S. and Mistruykov, A.A. (2005) Stages in the Development of the Darhad Dammed Lake (Northern Mongolia) during the Late Pleistocene and Holocene. Quaternary International, 136, 83-94. https://doi.org/10.1016/j.quaint.2004.11.010

[8] Gillespie, A.R., Burke, R.M., Komatsu, G. and Bayasgalan, A. (2008) Late Pleistocene Glaciers in Darhad Basin, Northern Mongolia. Quaternary Research, 69, 169-187. https://doi.org/10.1016/j.yqres.2008.01.001

[9] Orkhonselenge, A. (2016) Glacial Geomorphology of Mt. Munkh Saridag in the 
Khuvsgul Mountain Range, Northern Mongolia. Géomorphologie: Relief, Processes, Environment, 22, 387-396. https://doi.org/10.4000/geomorphologie.11596

[10] Kitov, A.D., Kovalenko, S.N. and Plyusnin, V.M. (2009) Results of the 100-Year Follow-Glacial Mountain Geosystems Array Munku-Sardyk. Geografiya i Prirodnye Resursy, 3, 101-108.

[11] Kitov, A.D., Kovalenko, S.N., Plyusnin, V.M. and Suvorov, E.G. (2015) Modern Changes of the High-Mountain Landscapes and Glaciation in Southern Siberia (Russia) by the Example of the Eastern Sayan Mountains. Environ Earth Science, 74, 1931-1946. https://doi.org/10.1007/s12665-015-4455-y

[12] Kovalenko, S.N. (2011) Glycialnay Geomorfologiy raionag. Munku-Sardyk. Formi lokalnogo oledeneniy dolin rek Muguvek and Belogo Irkuta. Vestn. kafedry geografii VSGAO, 1, 44-69.

[13] Kovalenko, S.N. (2014) O granicah i obiemah sovremennogo oledeneniy raiona g. Munku-Sardyk (Vostochniy Sayan). Vestn. kafedry geografii VSGAO, 1, 19-31.

[14] Jigj, S. (1975) Primary Feature of Mongolian Landforms. Institute of Geography \& Permafrost, Mongolian Academy of Sciences (MAS), Ulaanbaatar, 126 pp. [In Mongolian]

[15] Murzaev, E.M. (1952) The Description of Physical Geography of Mongolia. 2nd Edition, Moscow. [In Russian]

[16] National Atlas of the Peoples Republic of Mongolia (1990) Academy of Sciences of Mongolia and Academy of Sciences of USSR. Ulaanbaatar and Moscow, 156 pp.

[17] Dulamsuren, C., Hauck, M. and Mühlenberg, M. (2005) Vegetation at the Taiga Forest-Steppe Borderline in the Western Khentey Mountains, Northern Mongolia. Annales Botanici Fennici, 42, 411-426.

[18] Ministry of Environment and Green Development (MEGD), Government of Mongolia (2012) Tuul River Basin-Integradted Water Management Plan. Ulaanbaatar, 263.

[19] Atlas of Road of Mongolia (2014) Monsudar Pressing Ltd., Ulaanbaatar, 117 pp.

[20] Heyman, J., Hättestrand, C. and Stroeven, A.P. (2008) Glacial Geomorphology of the Bayan Har Sector of the NE Tibetan Plateau. Journal of Maps, 42, 42-62. https://doi.org/10.4113/jom.2008.96

[21] Morén, B., Heyman, J. and Stroeven, A.P. (2011) Glacial Geomorphology of the Central Tibetan Plateau. Journal of Maps, 7, 115-125. https://doi.org/10.4113/jom.2011.1161

[22] Fu, P., Heyman, J., Hättestrand, C., Stroeven, A.P. and Harbor, J.M. (2012) Glacial Geomorphology of the Shaluli Shan Area, Southeastern Tibetan Plateau. Journal of Maps, 8, 48-55. https://doi.org/10.1080/17445647.2012.668762

[23] Stroeven, A.P., Hättestrand, C., Heyman, J., Kleman, J. and Morén, B.M. (2013) Glacial Geomorphology of the Tian Shan. Journal of Maps, 9, 505-512. https://doi.org/10.1080/17445647.2013.820879

[24] Bolch, T. and Loibl, D. (2017) 2.06-GIS for Glaciers and Glacial Landforms. Reference Module in Earth Systems and Environmental Sciences Comprehensive Geographic Information Systems, 112-139. https://doi.org/10.1016/B978-0-12-409548-9.09639-1

[25] Benn, D.I. and Evans, D.J.A. (1998) Glaciers and Glaciation. Edward Arnold, London, $734 \mathrm{pp}$. 
[26] Lewis, W.V. (1960) Norwegian Cirque Glaciers. Royal Geographical Society Research Series, 4.

[27] Okishev, P.A. (2006) Topography and Glaciation Russian Altai. In: Okishev, P.A. and Narozhnyi, J.K., Eds., Problems of Geography of Siberia, Tomsk University Press, Tomsk, 39-55. 